\title{
A Transitional Cell Tumor of the Bladder in a Young Adult: A Case Report and Review of the Literature
}

\section{Genç Bir Yetişkinde Görülen Değişici Epitel Hücreli Mesane Tümörü: Olgu Sunumu ve Literatürün Gözden Geçirilmesi}

\author{
Hüseyin Koçan', Şiir Yıldııım², Enver Özdemir', Mehmet Yazıcl ${ }^{3}$, Erhan Erdoğan', Fuat Ernis Su', Mehmet Uhri' \\ 'University of Health Sciences, Kanuni Sultan Süleyman Training and Research Hospital, Clinic of Urology, İstanbul, Turkiye \\ ${ }^{2}$ University of Health Sciences, Kanuni Sultan Süleyman Training and Research Hospital, Clinic of Embryology and Histology, Andrology \\ Laboratory, istanbul, Turkiye \\ ${ }^{3}$ University of Health Sciences, Kanuni Sultan Süleyman Training and Research Hospital, Clinic of Pediatric Surgery, Istanbul, Turkiye \\ ${ }^{4}$ University of Health Sciences, Kanuni Sultan Süleyman Training and Research Hospital, Pathology Laboratory, Istanbul, Turkiye
}

\begin{abstract}
Bladder tumors are rarely seen in young people under the age of 40 . Its development after the exposure to industrial carcinogens for many years suggests that the environmental factors play a significant role in the development of transitional cell carcinoma of the bladder. The low prevalence of transitional cell carcinoma of the bladder in young people supports the existence of genetic component. Herewith, we present an 18-year-old patient without a history of exposure to any chemical agent and a review of the relevant literature.
\end{abstract}

Keywords: Bladder, transitional cell tumor, young adult

Öz

Mesane tümörü 40 yaşından genç insanlarda oldukça nadir görülmektedir. Endüstriyel karsinojenlere uzun yıllar maruz kalındıktan sonra gelişmesi, çevresel etkenlerin değişici epitel hücreli mesane tümörü gelişiminde önemli bir rolü olduğunu düşündürmektedir. Genç insanlarda nadiren de olsa değişici epitel hücreli mesane tümörü görülmesi genetik komponentin varlığını desteklemektedir. Bu olguda, herhangi bir kimyasal temas öyküsü olmayan 18 yaşında bir olgu literatür eşliğinde ele alınmıştır.

Anahtar Kelimeler: Mesane, değişici hücreli tümör, genç erişkin

\section{Introduction}

Transitional cell carcinoma accounts for 95\% of bladder cancers. Carcinosarcoma, leiomyosarcoma, sarcomatoid carcinoma, papillomas and adenomatous polyps are rare. The etiologic factors in transitional cell carcinoma include smoking, occupational carcinogens, schistosomiasis, cyclophosphamide, male gender, age, radiotherapy, racial and genetic factors. Young people are considered to be more genetically predisposed since a latent period is required for chemical effects.

\section{Case Presentation}

An 18-year-old male patient presented to our outpatient clinic with the complaint of macroscopic hematuria. There was no history of disease or previous surgery. Ultrasound examination of the urinary tract revealed a space occupying mass measuring 5-6 $\mathrm{mm}$ in diameter at the right lateral wall of the bladder bulging into the lumen (Figure 1). Cystoscopy showed a papillary tumor formation attaching to the right lateral wall of the bladder by a stalk with a diameter of $5 \mathrm{~mm}$. Transurethral

Correspondence: Hüseyin Koçan MD, University of Health Sciences, Kanuni Sultan Süleyman Training and Research Hospital, Clinic of Urology, İstanbul, Turkiye Phone: +90 5054048903 E-mail: dr_kocan@yahoo.com

Received: 29.07.2015 Accepted: 21.12.2015

Cite this article as: Koçan H, Yıldııım Ş, Özdemir E, Yazıcı M, Erdoğan E, Su FE, Uhri M. A Transitional Cell Tumor of the Bladder in a Young Adult: A Case Report and Review of the Literature. J Urol Surg 2017;4:76-78.

๑Copyright 2017 by the Association of Urological Surgery / Journal of Urological Surgery published by Galenos Publishing House. 
resection was performed. There was no history of smoking and exposure to occupational carcinogens and, the pathological examination evaluated as low-grade pTa (Figure 2). Recurrent tumor formation was not observed during the 2-year follow-up.

\section{Discussion}

Bladder tumor is rare in children and young adults and the peak incidence is in the sixth decade of life (1). Series of transitional cell tumor of the bladder in young patients are limited in the literature. In a study by Aboutaieb et al. (2) including 26 patients,

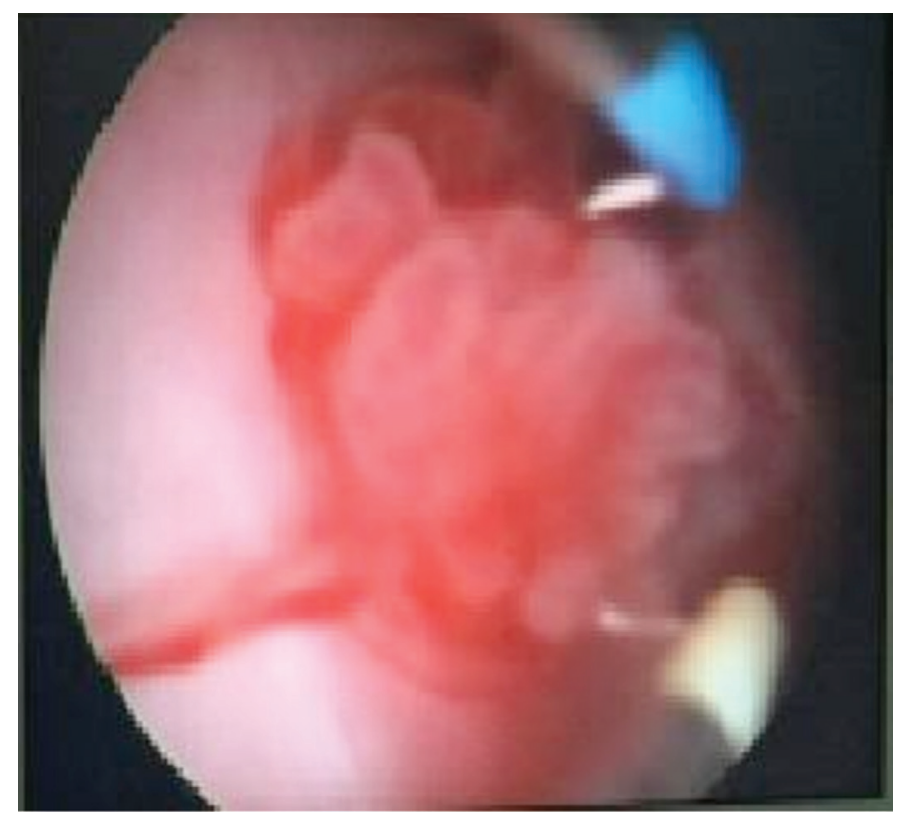

Figure 1. Cystoscopy of the bladder. Papillary tumor is seen attaching to the right lateral wall of the bladder

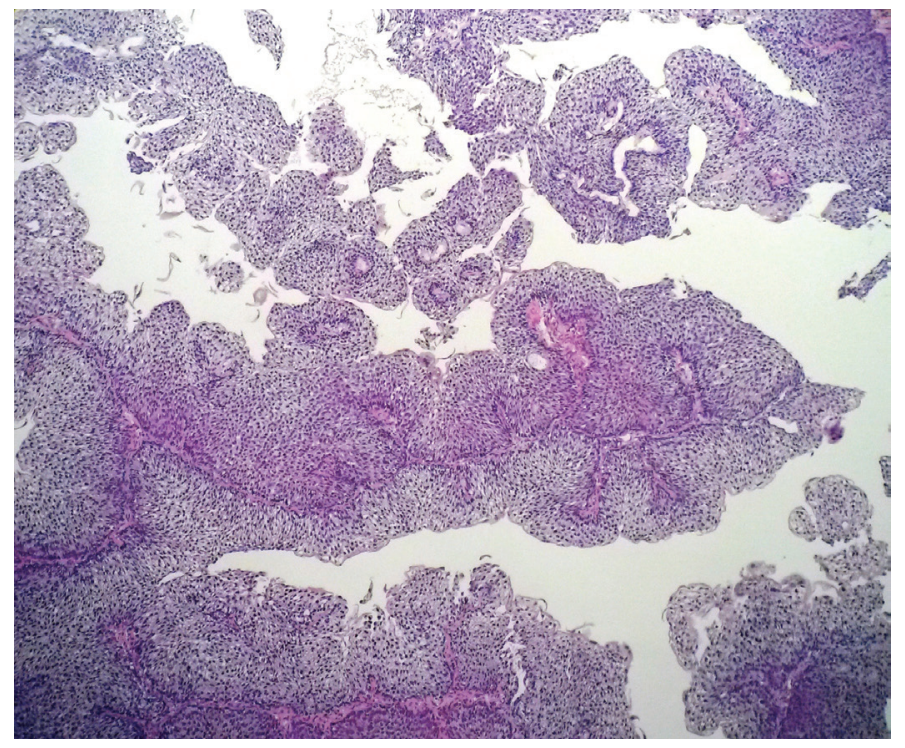

Figure 2. Low-grade pTa. Pleomorphic tumor cells arranged on fibromuscular stroma with enlarged nuclei and infrequent mitotic activity (hematoxylin and eosin, $x 100)$
8 patients were under the age of 30 and the youngest one was 20 years old. Of the cases under the age of 40 reported by Ozbey et al. (3), the youngest and the only one of the patients was 19 years old. Ikeda et al. (4) have reported a case of an 18-year-old female and Laurenti et al. (5) have reported a case of a 13-yearold boy. The case we present was an 18-year-old male patient.

The data shows that bladder tumors in young people have a low grade and stage and the prognosis is favorable $(2,3)$. The tumor in our patient was low grade and stage and no recurrence of the tumor was detected in 2 years of follow-up.

The disease may occur at any age including childhood even though the median years of age has been reported to be 69.0 for males and 71.5 for females $(6,7)$. Bladder tumor has not been considered due to young age and the patient has been treated for urinary infection.

Linn et al. (8) have reported that the aneuploidy of chromosome 17 was common, particularly in carcinoma in situ and invasive bladder cancer and, they have showed that overexpression of protein p53 might predispose to transitional cell tumor of the bladder in young patients. Chemical carcinogens and smoking are substantial in the etiology of bladder tumor. Bladder tumor is considered to be a middle-aged disease because of the requirement of latent period for the occurrence of the effects of these factors. Genetic predisposition is accused in young patients because of the lack or absence of exposure to these substances. Some studies indicated that the risk of bladder tumor was increased 1.5-2 times in patients with a positive family history $(9,10,11)$. There was not any history of contact with carcinogens, positive family history and smoking history in our patient.

In patients younger than 20 years of age, bladder tumor is more common in males (12). Bladder tumor is more common in male gender in all age groups.

Although bladder tumors in young people have usually a low grade and stage and the prognosis is favorable, cases of invasive tumor have also been reported. Few of these were 31-month (13), 14-year (14) and 28-year-old (1) patients.

The case we have presented was an 18-year-old male having non-invasive transitional cell tumor of the bladder.

\section{Ethics}

Informed Consent: Consent form was filled out by the participant.

Peer-review: Externally peer-reviewed.

\section{Authorship Contributions}

Concept: H.K., E.Ö., Design: H.K., S..Y., Data Collection or Processing: H.K., Ş.Y., Analysis or Interpretation: H.K., M.Y., M.U., Literature Search: H.K., E.E., F.E.S., Writing: H.K., S..Y., M.Y. 
Conflict of Interest: No conflict of interest was declared by the authors.

Financial Disclosure: The authors declared that this study has received no financial support.

\section{References}

1. Nabbout P, Eldefrawy A, Engles CD, Culkin DJ, Slobodov G. Muscle-invasive bladder cancer in a young adult: a case report and a review of the literature. Cent European J Urol 2013;66:185-187.

2. Aboutaieb R, Dakir M, Sarrf I, el Moussaoui A, Bennani S, el Mrini M, Meziane F, Benjelloun S. Bladder tumors in young patients. Prog Urol 1998;8:43-46.

3. Ozbey I, Aksoy Y, Biçgi O, Polat 0, Okyar G. Transitional cell carcinoma of the bladder in patients under 40 years of age. Int Urol Nephrol 1999;31:655659 .

4. Ikeda I, Terao T, Nakagomi K, Masuda M, Hirokawa M. Recurrent transitional cell carcinoma of the bladder in a young woman: report of a case. Hinyokika Kiyo 1992;38:1261-1263.

5. Laurenti C, De Dominicis C, Mattioli D, Rocchegiani A, Franco G, dal Forno S, Iori F. Transitional cell neoplasm of the bladder in childhood: presentation of a clinical case. Arch Esp Urol 1993;46:51-54.

6. Lynch CF, Cohen MB. Urinary system. Cancer 1995;75:316-329.
7. Campbell MF, Walsh PC, Retik AB. Campbell's Urology. 8th ed. Vol. 4, Philadelphia, Saunders, 2002.

8. Linn JF, Sesterhenn I, Mostofi FK, Schoenberg M. The molecular characteristics of bladder cancer in young patients. J Urol 1998;159:14931496.

9. Kramer AA, Graham S, Burnett WS, Nasca P. Familial aggregation of bladder cancer stratified by smoking status. Epidemiology 1991;2:145-148.

10. Goldgar DE, Easton DF, Cannon-Albright LA, Skolnick MH. Systematic population-based assessment of cancer risk in first-degree relatives of cancer probands. J Natl Cancer Inst 1994;86:1600-1608.

11. Altaylı E, Güneş $S$. Mesane Kanseri Gelişiminde Moleküler Mekanizmaların Rolü. Türkiye Klinikleri J Med Sci 2011;31:191-205.

12. Fine SW, Humphrey PA, Dehner LP, Amin MB, Epstein JI. Urothelial neoplasms in patients 20 years or younger: a clinicopathological analysis using the world health organization 2004 bladder consensus classification. J Urol 2005;174:1976-1980.

13. Lezama-del Valle P, Jerkins GR, Rao BN, Santana VM, Fuller C, Merchant TE. Aggressive bladder carcinoma in a child. Pediatr Blood Cancer 2004;43:285288.

14. Scott AA, Stanley W, Worsham GF, Kirkland TA Jr, Gansler T, Garvin AJ. Aggressive bladder carcinoma in an adolescent. Report of a case with immunohistochemical, cytogenetic, and flow cytometric characterization. Am J Surg Pathol 1989;13:1057-1063. 